\title{
Simulation Model Pattern Distribution Sediment at Ambon Bay, Indonesia
}

\author{
Mukhsan Putra Hatta ${ }^{1,}$, Muhammad Arsyad Thaha ${ }^{1}$,'Marthen P Lakatua ${ }^{2}$ \\ ${ }^{1}$ Departement Civil Engineering, Hasanuddin University, Makasar, Indonesia \\ ${ }^{2}$ Departement Civil Engineering, The Mollucan Christian University of Indonesia, Ambon, Indonesia
}

\begin{abstract}
The sedimentation occurring in the outer Ambon bay as a result of the effluent from Way Ruhu river causes the reduction the mouth of the outer Ambon Bay, so that it influences the current movement pattern and sediment distribution. This research aimed at analyzing the current movement pattern and sediment distribution pattern in the outer Ambon bay using two scenarios: with the reclamation and without reclamation. The research used the numerical model of MIKE 21DHI with modules of the hydrodynamic and mud transport. The research result indicates that the simulation current velocity with the absence of reclamation ranged from $0.0-0.4 \mathrm{~m} / \mathrm{s}$, while with the presence of the reclamation, the current velocity is slightly higher that is between $0.0-0.6 \mathrm{~m} / \mathrm{s}$ the various velocity patterns. The sediment distribution pattern in the outer Ambon bay as the result of the effluent from the way Ruhu river follows the current movement. If the conditions leading to the tide and the highest tide, the sediment going out from way Ruhu river is pushed into the bay and vice versa, when the condition leading to the recede and lowest recede, the sediment concentration is pulled out from the bay. The suspended sediment concentration is between $0.002 \mathrm{~kg} / \mathrm{m} 3-0.030 \mathrm{~kg} / \mathrm{m} 3$ with the various patterns. The suspended sediment concentration to the condition without reclamation is more collecting if compared with the suspended sediment concentration by the presence of the distributing reclamation because of current velocity effect.
\end{abstract}

\section{Introduction}

Ambon city has the Gulf consisting of the Bay of Ambon In Ambon Bay and beyond. In this Bay there are also several large and small rivers which boils down to the Bay of Ambon Out include River Way Ruhu. The river has a length of approximately $4.5 \mathrm{~km}$, has a large water areas upstream and downstream at the village of Galala. In the Way many Ruhu deposition of sediment that occurs mainly in the estuary towards the Bay of Ambon. The observations show that the River upstream of the River in a State of stable and water flow of the river is quite clear and invisible existence of sediments that could potentially cause the flow of sediments or signs of avalanche cliff.

Sedimentation also resulted in the closure of the estuary mouth of the river where Ruhu way be small thus leading to flooding in the rainy season in the surrounding area [1]. Until now there has been no local government efforts to deal with it seriously.

\footnotetext{
* Corresponding author: mukhsan.hatta@gmail.com
} 
In addition this sedimentation also cause the lighthouse lamps in pairs on the two side of the Bay as a sign of shallow areas in order to be able to show the direction of cruise in and out of the Gulf is also experiencing displacement, which showed lower distances along with the increased time. As a sign of that growing a small or narrow Bay navigable distance ships to get in and out of the Bay of Ambon. If this condition is allowed to continue, it will be a serious impact on cruise traffic in the Bay of Ambon.

In addition to the flow diminution caused by the exile of the way that Groove, around Ruhu also has built a pedestrian bridge linking the village of Galala Poka village and as well as the reclamation occurs along the coast of the estuary of the river way Ruhu westward. Of course all this would bring impact on circulation flow in and out of the Gulf as well as the spread of sediments [2,3].

This research aims to know the pattern of spread of sediments in the Bay of Ambon outside as a result of the exile of the way using numerical modeling Ruhu with FM Mike21 software from Danish Hydraulic Institute. This modeling uses two scenarios i.e. scenarios to see the pattern of flow and sediment dispersion without any reclamation and construction of the bridge, known as the scenarios one and with the reclamation and there is a bridge called as two scenarios. This model is expected to be a numerical model in General for other research on sediment distribution pattern of the mouth of the River, especially in the Gulf.

\section{Materials and methods}

\subsection{The location and design of the Research}

The location of the research conducted in the Bay of Ambon in particular Ambon Bay on the outside which is at coordinates with a range of $03^{\circ} 56^{\prime}$ up to $35^{\circ} 73^{\prime}$ 'South latitude and $128^{\circ} 10^{\prime}$ up to $128^{\circ} 24^{\prime}$ East longitude. This study uses two scenarios i.e. condition without reclamation and reclamation with hydrodynamics and transport pattern for the distribution of mud sediments.

\subsection{Methods of data collection}

In this study uses two data sources namely, primary data and secondary data. Required data is the data of the bathymetry, tidal data, data, data flow, wind speed, wave data, data streams and sediment discharge $[4,5]$.

\subsection{Materials and tools}

This research using materials and tools in the form of samples, sediments, GPS Garmin, signs the measure, Theodolite, Koden Echosounder CSV.

\subsection{Data collection}

The data that is required in this form of research data, bathymetry, tidal data, data speed and direction of the currents, wind data, sediment grain size data. 


\subsection{Methods of implementation}

The method this research using a numerical model with hydrodynamic and mud transport module of the Mike 21.

\subsection{Data analysis}

This modeling using Numerical models of the Mike $21 \mathrm{HD}$ that is suitable for the Gulf Coast and estuaries [6]. The equation of conservation of mass and momentum, describes the flow and elevation of water face [7]:

The equation continuity,

$$
\frac{\partial \zeta}{\partial t}+\frac{\partial p}{\partial x}+\frac{\partial q}{\partial y}=\frac{\partial d}{\partial t}
$$

The equation of momentum $\mathrm{x}$ direction,

$$
\begin{gathered}
\frac{\partial p}{\partial t}+\frac{\partial}{\partial x}\left(\frac{p^{2}}{h}\right)+\frac{\partial}{\partial y}\left(\frac{p q}{h}\right)+g h \frac{\partial \zeta}{\partial x}+\frac{g p \sqrt{p^{2}+q^{2}}}{C^{2} \cdot h^{2}}-\frac{1}{\rho_{w}}\left[\frac{\partial}{\partial x}\left(h \tau_{x x}\right)+\frac{\partial}{\partial y}\left(h t_{x y}\right)\right] \\
-\Omega_{q}-f V V_{x}+\frac{h}{\rho_{w}} \frac{\partial}{\partial x}\left(p_{a}\right)=0
\end{gathered}
$$

The equation of momentum y direction,

$$
\begin{aligned}
& \frac{\partial q}{\partial t}+\frac{\partial}{\partial y}\left(\frac{q^{2}}{h}\right)+\frac{\partial}{\partial x}\left(\frac{p q}{h}\right)+g h \frac{\partial \zeta}{\partial y}+\frac{g p \sqrt{p^{2}+q^{2}}}{C^{2} \cdot h^{2}}-\frac{1}{\rho_{w}}\left[\frac{\partial}{\partial y}\left(h \tau_{y y}+\frac{\partial}{\partial x}\left(h \tau_{x y}\right)\right)\right] \\
& -\Omega_{p}-f V V_{y}+\frac{h}{\rho_{w}} \frac{\partial}{\partial x y}\left(p_{a}\right)=0
\end{aligned}
$$

Where:

$$
\begin{array}{ll}
h(x, y, t) & =\text { water depth } \\
d(x, y, t) & =\text { water depth in various time }(\mathrm{m}) \\
\zeta(x, y, t) & =\text { surface elevation }(\mathrm{m}) \\
p, q(x, y, t) & =\text { flux density in the direction of } \mathrm{x} \text { and } \mathrm{y}(\mathrm{m} 3 / \mathrm{s} / \mathrm{m})=(\mathrm{uh}, \mathrm{vh}) \\
(\mathrm{u}, \mathrm{v}) & =\text { depth averaged velocity in the } \mathrm{x} \text { and } \mathrm{y} \text { directions } \\
C(x, y) & =\text { prisoner Chezy }\left(\mathrm{m}^{1 / 2} / \mathrm{s}\right) \\
g & =\text { speed of gravity }(\mathrm{m} / \mathrm{s} 2) \\
f(V) & =\text { wind friction factor } \\
V, V_{x}, V_{y},(x, y, t) & =\text { wind speed in the direction of } \mathrm{x} \text { and } \mathrm{y}(\mathrm{m} / \mathrm{s}) \\
\Omega(x, y) & =\text { Coriolis parameter }(\mathrm{s}-1)
\end{array}
$$




$$
\begin{array}{ll}
p_{a}(x, y, t) & =\text { atmospheric pressure }(\mathrm{kg} / \mathrm{m} / \mathrm{s} 2) \\
\rho_{w} & =\text { density of water }(\mathrm{kg} / \mathrm{m} 3) \\
x, y & =\text { spatial coordinates }(\mathrm{m}) \\
t & =\text { time }(\mathrm{s}) \\
\tau_{x x}, \tau_{x y}, \tau_{y y} & =\text { component of effective shear stress }
\end{array}
$$

Mud Transport Module (MT) is a model application of cohesive sediment transport integrated with MIKE 21 Flow Model FM [8]. The regulatory equations used in this module are advection and dispersion $[9,10,11]$.

as follows:

$$
\frac{\partial \bar{c}}{\partial t}+u \frac{\partial \bar{c}}{\partial x}+v \frac{\partial \bar{c}}{\partial y}=\frac{1}{h} \frac{\partial}{\partial x}\left(h D_{x} \frac{\partial \bar{c}}{\partial x}\right)+\left(h D_{y} \frac{\partial \bar{c}}{\partial y}\right)+Q_{L} C_{L} \frac{1}{h}-S
$$

Where:

$$
\begin{array}{ll}
\bar{c} & =\text { average sediment concentration }(\mathrm{g} / \mathrm{m} 3) \\
u, v & =\text { flow velocity } \mathrm{x}, \mathrm{y}(\mathrm{m} / \mathrm{s}) \\
D_{x}, D_{y} & =\text { disperse coefficient }(\mathrm{m} 2 / \mathrm{sec}) \\
h & =\text { water depth }(\mathrm{m}) \\
S & =\text { precipitate } / \text { erosion }(\mathrm{g} / \mathrm{m} 3 / \mathrm{sec}) \\
Q_{L} & =\text { the incoming discharge per unit area }(\mathrm{m} 3 / \mathrm{s} / \mathrm{m} 2) \\
C_{L} & =\text { incoming sediment concentration }(\mathrm{g} / \mathrm{m} 3)
\end{array}
$$

\section{Research results}

Research results show that the current validation between the speed of the current model and the speed of flow measurement data does not vary much with the error amounted to $3.27 \%$. It is shown that the model can be used to run transport sediment model.

The simulation performed with two scenarios on four conditions. The first scenario i.e. where the process of hydrodynamics occurring without any of the reclamation, the second scenario is being carried out in the presence of the reclamation. To the four conditions in question is the conditions leading to the highest tide conditions, tides, conditions leading to recede and the lowest low tide conditions.

Hydrodynamics simulations indicate that current patterns that occur due to the influence of the movement of the elevation of the face of the tides. The output of this simulation is the pattern of the flow in Ambon bay for the conditions leading to the highest tide, tide, into the ebbs and the lowest low tide. Hydrodynamics simulation results show the highest tide, face the water reach 2.1 meters which occurred at a time the 4th step in modeling. While the lowest low tide water face is high, $0.50 \mathrm{~m}$ happens at time step to-300 from modeling. For the conditions leading to the tide occurs at the time of the 13th step and conditions towards the downs are on the time step to-32.

Tidal current speed towards without reclamation in the range $0.0-0.3 \mathrm{~m} / \mathrm{s} \mathrm{m} / \mathrm{s}$ and the speed of flow with the reclamation in the range $0.0-0.4 \mathrm{~m} / \mathrm{s} \mathrm{m} / \mathrm{s}$ in figure 1 the highest tidal condition when the speed of the flow moving faster between $0.0 \mathrm{~m} / \mathrm{s}-0.4 \mathrm{~m} / \mathrm{s}$ without reclaiming and flow velocity in figure 2 with the reclamation in the range $0.0-0.6 \mathrm{~m} / \mathrm{s} \mathrm{m} / \mathrm{s}$. As the conditions toward the ebb and flow of the current move inverted from the inner bay 
towards the outer Bay or from the East towards the Southwest with a speed varying between $0.0-0.4 \mathrm{~m} / \mathrm{s} \mathrm{m} / \mathrm{s}$ without reclaiming and $0.0-0.5 \mathrm{~m} / \mathrm{s} \mathrm{m} / \mathrm{s}$ with reclamation. In figure 3 the lowest low tide conditions to speed the flow without reclamation in the range $0.0-0.3$ $\mathrm{m} / \mathrm{s} \mathrm{m} / \mathrm{s}$ and the speed of the flow to the lowest low tide conditions in the range $0.0-0.4 \mathrm{~m} / \mathrm{s}$ $\mathrm{m} / \mathrm{s}$ with the reclamation.

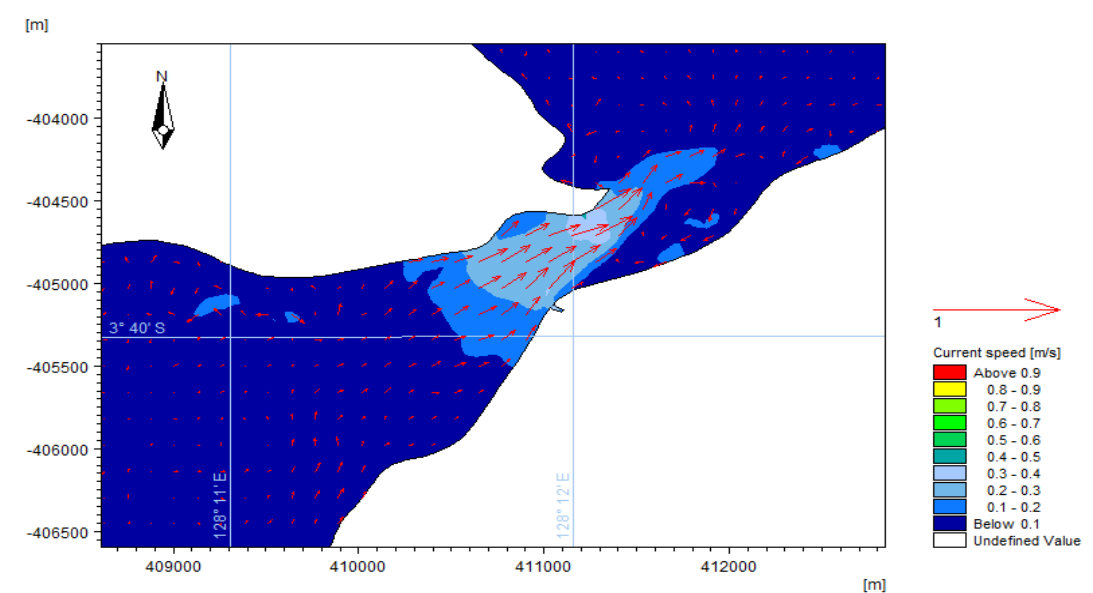

Fig. 1. Current velocity at high tide highest without reclamation

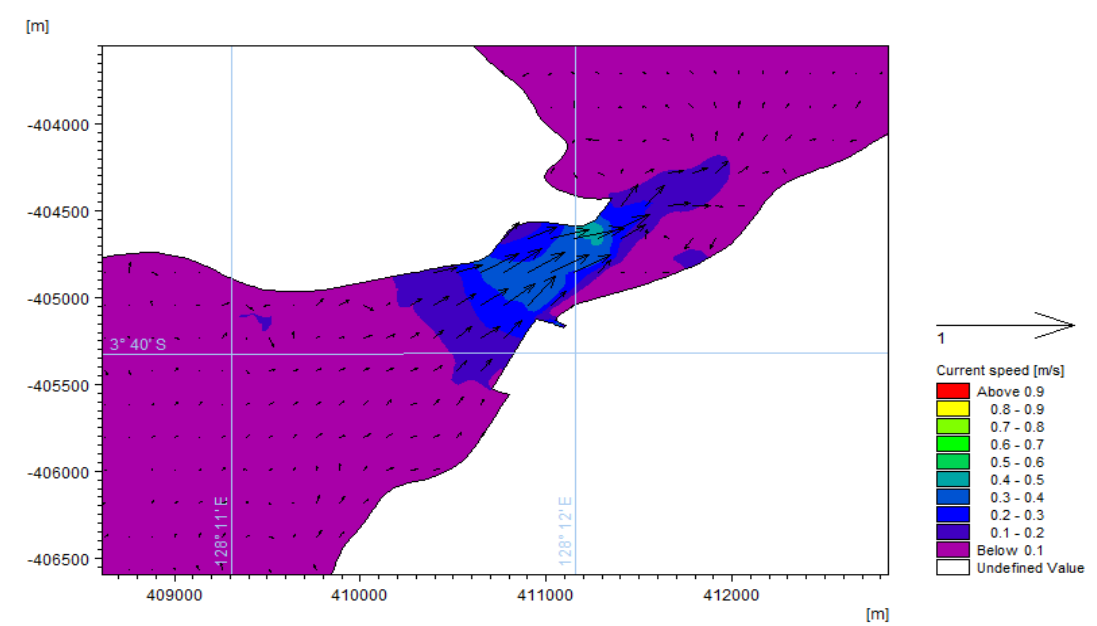

Fig. 2. Current speed at high tide highest with reclamation 

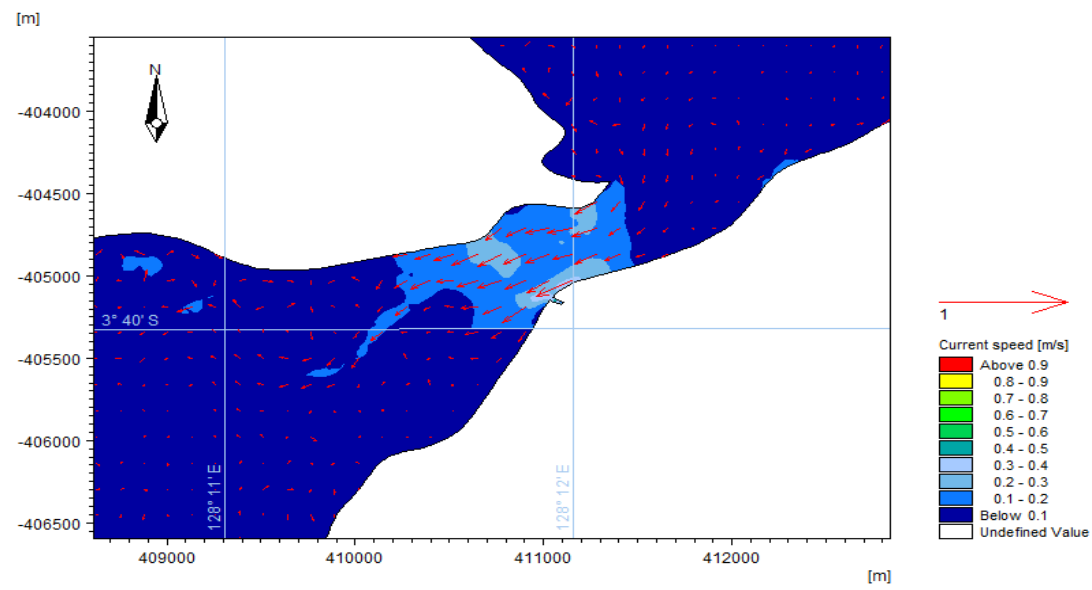

Fig. 3. Current velocity at low tide lowest without reclamation

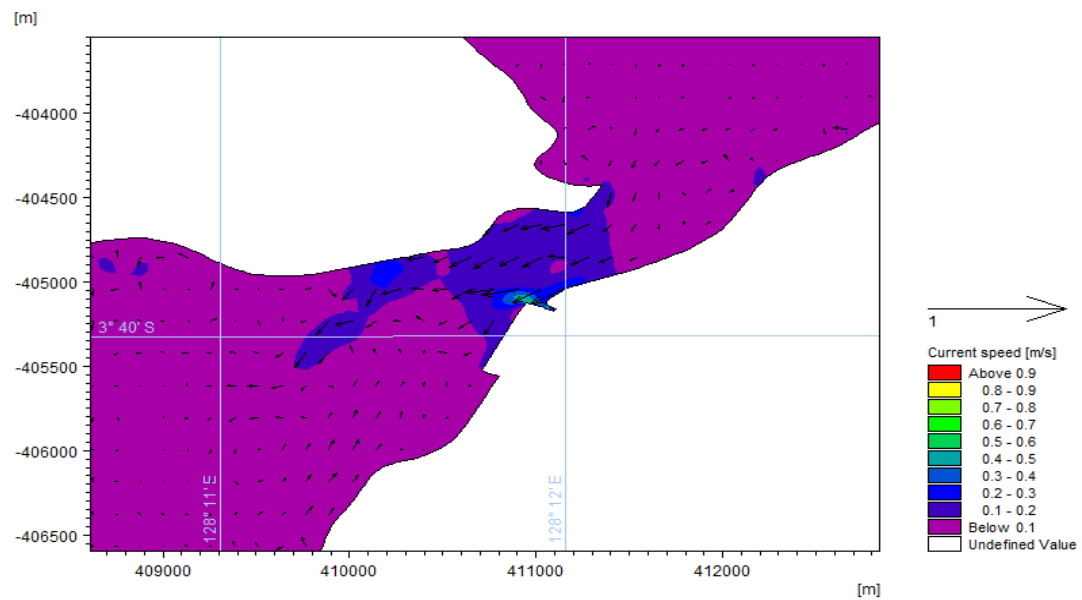

Fig. 4. The pattern of distribution of suspended sediment without reclamation when the time step $=164$

Simulation of sediment transport is conducted to find out the pattern of the spread of sediments occurs. The output of this simulation is a great form of distribution patterns of suspended sediment concentration, bed level change. On the simulation of sediment transport, the source of the sediment is assumed to be simply derived from material which is get carried away by the flow of the river.

The results of the simulation of sediment transport for some time step i.e., $t=2, t=3, t$ $=139, \mathrm{t}=143$ and $\mathrm{t}=164$ indicates that the movement of sediments affected by elevation faces the tides. From figure 4 for time step $t=164$ indicates sediment dispersion pattern without reclaiming that flows out of the River with the variation of the concentrations of $0.004 \mathrm{~kg} / \mathrm{m} 3-0.030 \mathrm{~kg} / \mathrm{m} 3$, while in figure 5 with the spread of sediment concentration of reclamation ranged from $0.004 \mathrm{~kg} / \mathrm{m} 3-0.030 \mathrm{~kg} / \mathrm{m} 3$. 


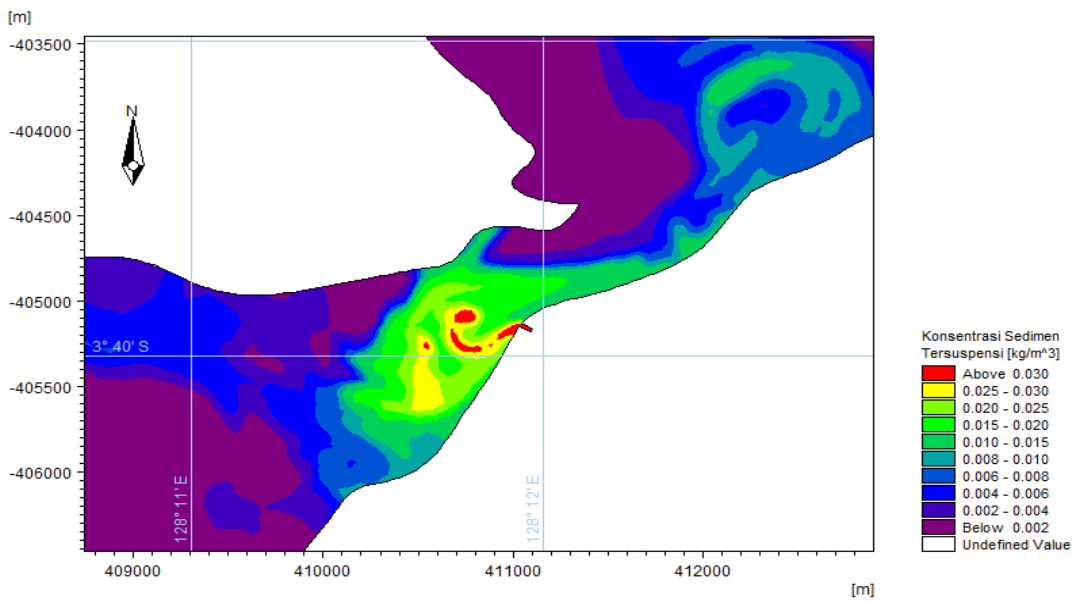

Fig.5. The pattern of distribution of suspended sediment with the reclamation of the moment time step $=164$

\section{Discussion}

This research showed that when the tide moving water from outside the Gulf toward the Gulf in or from the Southwest toward the Northeast. The speed of the flow without reclamation in the range $0.0-0.3 \mathrm{~m} / \mathrm{s} \mathrm{m} / \mathrm{s}$ maximum flow Speed. of $0.3 \mathrm{~m} / \mathrm{s}$ with a small pattern that occurs around the mouth of the Bay. The speed of the flow with the reclamation in the range $0.0-0.4 \mathrm{~m} / \mathrm{s} \mathrm{m} / \mathrm{s}$ maximum flow Velocity occurs. the pattern slightly enlarged at the mouth of the Gulf when compared to without reclamation. The highest tide conditions to speed the flow of moving more quickly between $0.0 \mathrm{~m} / \mathrm{s}-0.4 \mathrm{~m} / \mathrm{s}$ without reclaiming and $0.0 \mathrm{~m} / \mathrm{s}-0.6 \mathrm{~m} / \mathrm{s}$ with reclamation. This speed increase is caused due to constriction around the mouth of the Bay as a result of reclamation on the side of the mouth of the River along the coast (Triatmodjo, 2012). When the condition of the moving direction of the flow ebbs toward turning from the Gulf towards the outer Bay or from the East towards the Southwest with a speed varying between $0.0 \mathrm{~m} / \mathrm{s}-0.4 \mathrm{~m} / \mathrm{s}$ without reclaiming and $0.0 \mathrm{~m} / \mathrm{s}$ $-0.5 \mathrm{~m} / \mathrm{s}$ with reclamation. The lowest low tide conditions to speed the flow of without reclamation ranges between $0.0 \mathrm{~m} / \mathrm{s}-0.3 \mathrm{~m} / \mathrm{s}$ and $\mathrm{m} / \mathrm{s} 0.0-0.4 \mathrm{~m} / \mathrm{s}$ with reclamation.

The results of the simulation of sediment transport for time step $t=2$ where the movement of sediments affected by tides, then the pattern of spread of sediments without reclamation sediment flowing outward shows of the river and began to spread along the coastline to the West variation of concentrations of $0.004 \mathrm{~kg} / \mathrm{m} 3-0.030 \mathrm{~kg} / \mathrm{m} 3$, whereas with reclamation sediment patterns spread gathered toward the front of the mouth of the River with the variation of concentration between $0.004-0.030 \mathrm{~kg} / \mathrm{m} 3$. The pattern of the movement towards the front of the estuary is caused due to the narrowing occurs at the left side of the River as a result of reclamation [11].

At time step $=3$ for the conditions leading to install when compared between scenario one scenario two, and then with the narrowing occurs at the mouth of the reclamation of the Bay so that the speed of the high current is able to parse the concentration of sediment that accumulates, so the appropriate sediment concentration spread faster when compared to without reclamation. Sediment dispersion pattern during install to time step $=139$, where sediment dispersion pattern has spread extends to various places along the beach when compared to time step $=3$. Sediment dispersal patterns are strongly influenced by the speed 
of the current move it. When a high flow speed the movement of sediment is more scattered and vice versa when the current speed of low sediment dispersion pattern as if gathering.

At time step $=143$ for the condition without suspended sediment concentration of reclamation with a value above $0.030 \mathrm{~kg} / \mathrm{m} 3$ more were around the mouth of the Bay while the suspended sediment concentration with reclamation over $0.030 \mathrm{~kg} / \mathrm{m} 3$ is very small due to the influence of speed. The concentration of suspended sediments with concentrations between $0.0060 .008 \mathrm{~kg} / \mathrm{m} 3 \mathrm{~kg} / \mathrm{m} 3$

The continuous simulation of the process will be seen suspended sediment dispersal pattern is more widespread in coastal areas such as on a time step $=164$ to conditions without reclamation where the concentration of sediments spread more widely through to the inner part of the Gulf. The amount of suspended sediment concentration above 0.030 $\mathrm{kg} / \mathrm{m} 3$ for the reclamation condition with fewer at the mouth of the Gulf in comparison with the reclamation, but on conditions with sedimentary concentrations of suspended reclamation between $0.006 \mathrm{~kg} / \mathrm{m} 3-0.008 \mathrm{~kg} / \mathrm{M} 3$ more dominant on the inner part of the Gulf. This showing that the influence of tidal currents with high speed capable of pushing as well as unravel the concentration of sediment at the mouth of the Bay to be thrust into the Gulf when the tide receding and vice-versa in case not all sediment can draw out by the current.

\section{Conclusions and suggestions}

From the results of the analysis it can be concluded that the pattern of movement of the currents in the Bay of Ambon when outside conditions towards the highest tides and tidal currents in the Bay of Ambon is moving from the direction of the outside of the Bay or the southwest into the Gulf or the Northeast. The speed of the flow simulation without reclamation in the range $0.0-0.4 \mathrm{~m} / \mathrm{s} \mathrm{m} / \mathrm{s}$, while in the presence of the reclamation of slightly higher flow velocities between $0.0 \mathrm{~m} / \mathrm{s}-0.6 \mathrm{~m} / \mathrm{s}$ velocity patterns vary. The pattern of sediments deployment in the outer bay of Ambon as a result of the effluent from the river way Ruhu follows the current movement, if the condition leading to the highest tides and tide, then the sediments out of the river way Ruhu driven enters into the Gulf and vice versa when conditions towards the lowest low tide ebbs and the concentration of sediment pulled out of the Gulf. Suspended sediment concentrations were between $0.002 \mathrm{~kg} / \mathrm{m} 3-0.030$ $\mathrm{kg} / \mathrm{m} 3$ with a varied pattern for either reclamation condition and without reclamation. The concentration of suspended sediments to conditions without reclaiming more accumulates when compared with concentrations of suspended sediments with the reclamation are spread because of the influence the speed of the flow. The suggestions can be submitted is preferably running simulations done with time and output simulation is longer so that more accurate simulation results and validation are not performed with one parameter only.

\section{References}

1. Danish Hydraulic Institute. User Guide and reference manual of MIKE-21 Coastal Hydraulics and Oceanography hydrodynamic module: Danish Hydraulic Institute, (2014)

2. Danish Hydraulic Institute. Mud transport Module - Scientifics Documentation: Danish Hydraulic Institute (2014)

3. G.R Dean \& R.A. Dalrymple, Coasltal Processes with Engineering Aplications. London: Cambriage University Press (2004)

4. M.P. Hatta, A. Tai, S. Yano, R. Rajar, and T. Komatsu, Effect of Geometry Alteration on Hydrodynamic Pattern in a Semi-Enclosed By (Study Case of the 
Ariake Bay), Proc. of 15th Congress of Asia Pacific Devision International Association of Hydraulic Engineering and Research, pp 753-760. (2006)

5. M.P. Hatta, A. Tai and M. I. Haerik, Water Mass Structure Around Makassar Coast in Dry Season. Proc. of. 13th Indonesian Association of Oceanologists (ISOI) (2016).

6. Pallu S. Teori Dasar Angkutan Sedimen di dalam Saluran Terbuka. Makassar: CV.Telaga Zamzam. (Indonesia) (2012)

7. R.M. Sorensen, Basic Coastal Engineering. USA: Springer (2006)

8. A. Tai, M. Hatta, , S. Yano, T. Saita and T. Komatsu, Numerical Tesrs on Mechanisms of Nonunifrom Velocity Profile in Ariake Sea, Proc. Of Techo-Ocean 2006 and 19th JASNAOE Ocean Engineering Symposium (2006)

9. Van Rijn L.C. Principles of Sediment Transport in Rivers, Estuaries and Coastal Seas, Delft Hydraulics. Netherland, (1993)

10. C.T. Yang Sedimen Transport, Theory and Practice. Toronto: McGraw-Hill Companies, Inc. (1996) 